will be remembered that shortly after Mr. McCarthy's and Capt. Gill's journeys into Burmah, Mr. Cameron performed the same feat, and was very anxious to return to $Y$ iunnan by the same route Being forbidden, however, to do so hy the Indian Government, he went, by way of Rangoon and Singapore, to the newlyopened port of Yakhoi, in the extreme south of China. From this place he made a long journey in the interior, going through parts of the provinces of Kwangtung, Kwangsi, Kweichow, and Yünnan, in fact, across the whole south of China Proper, and visiting places where Europeans had never been seen before. Since accomplishing that arduous undertaking, Mr. Cameron has made another Iong journey through parts of the provinces of Kwangtung Kiangsi, Fokhien, and Chekiang. In a remote part of the first-named province, near Shao-chow.fu, he noticed a novel method of transporting stones from a hill-top to the river. side, A zigzag path was made lown the hill-side, hollowed in the centre; on it a loaded sledge was placed and set in motion, the path being kept slippery by water poured on it by a man who appeared to have no other occupation. Nearer the border of the province the country people had a peculiar mode of preparing the ground for rice, in that they made straight rows and then crossed them, using a rake-like instrument with wheels insteed of teeth. In the east of the Kiangsi province Mr. Cameron mentions finding the tea-plant growing wild on the motntain sides, and forming with other shrubs a fine cover for game.

AT the annual meeting of the Russian Geographical Society the great gold medal was not awarded ; the gold medal of Count Lütke was awarded to Prof. Inostrantseff, for his geological work on the district of Povyenets (government Olonets). Small gold medals were awarded to M. Zolotnitsky, for the compilation of a dictionary of the Chouvashes language and researches into this language ; to M. Orloff, for statistical works on the Government of Moscow ; to General Stubendorf, for his continuous works in geography : to M. Kouropatkin, for his work on "Kashgaria ;" M. Moshkoff, for the levelling in Siberia ; M. Pyevtsoff, for his paper on Jungaria; and to M. Polyakoff, for his researches into the stone period in Russia. Silver medals were awarded in great number :- to $M$. Tikhonravoff, for his works during the Anthropological Exbibition at Moscow; MM. Lipin and Portsevitch, for work done during the exploration of the Obi and Yenissei watershed; M. Petrussevitch, for the exploration of the Amu River; M. Matussovsky, for his description of the highways in Western Mongolia; M. Yanovsky, for meteorological observations on the Askold Island; M. Listoff, for researches into the freezing of the Ketz salt lake; MM. Gellmann, Polouyanovsky, Stoulchinsky, and Petrovsky, for the levelling in Siberia; and to several others for ethnographical and statistical works.

IN the December number of thc Paris Geographical Society's Bulletin, M. De Ujfalvy gives a pretty full account of Kulja, apropos of the existing trouble between Russia and China as to its possession. M. J. Barraude concludes his translation of the long Russian paper on the Amu and Uzbu; and M. de Bizemont brings together the meteorological observations of Abbé Desgodins, on the meteorology of Tibet. M. Jametel describes the various routes from Jungaria to Tibet, after Chinese documents; and M. A. Lomonosof gives the itinerary from Patta-Kasar to Herat, followed by Col. Srodek of in 1878 .

\section{HISTORY OF RESEARCH AMONG THE FOSSIL FISHES OF SCOTLAND 1}

A LTHOUGH works containing notices of fossil fishes had appeared on the Continent as early as the fifteenth century, the earliest work descriptive of their occurrence in Scotland was Ure's "History of Rutherglen and East Kilbride," which was published in 1793, in which, among other Carboniferous fossils, several relics of the fishes of that epoch were figured. These are mostly the teeth of Selachii, or sharks, but one of them is a portion of the mandible of the gigantic ganoid fish now known as Rhizodus Hibberti. It was not, however, until the end of the third and commencement of the fourth decades of the present century that the palæichthyological treasures of the country began to attract any real attention.

In the year 1827 Sedgwick and Murchison, who had been exploring the sedimentary rocks of the north of Scotland,

I Being extracts from an Address given to the Royal Physical Society of Edinburgh, by Ramsay H. Traquair, M.D. despatched to Cuvier, for his opinion, a number of fossil fishes which they had found in the dark schists of Caithness; and they sent other specimens to Valenciennes and Pentland. In I828 they communicated to the Geological Society of London a paper "On the Structure and Relations of the Deposits contained between the Primary Rocks and the Oolitic Series in the North of Scotland," in which they founded the genus Dipterus, giving excellent figures of four supposed species. Cuvier's opinion was to the effect that these fishes were allied to the Lepidosteus, or bony pike of North America, and belonged, like it, to his division of Malacopterygii abdominales. The genus Osteolepis was also mentioned on the authority of Valencieanes and Pentland, with a figure of what is apparently a plate of Coccosteus, but which the authors at the time considered as having belonged to a "tortoise nearly allied to Trionyx."

In I827 Fleming had also obtained from the Upper Old Red Sandstone of Fifeshire certain organic remains, of which in the same year he published a preliminary notice in a local newspaper. These were, in fact, the scales of the fish, which afterwards received the now well-known name of Holoptychius.

A year afterwards, scales and plates of fishes were found in the upper "Old Red" of Clashbennie, in Perthshire, and were by some at first considered to be oyster shells! But Fleming, at once perceiving their real nature, prepared a short notice, "On the Occurrence of the Scales of Vertebrated Animals in the Old Red Sandstone of Fifeshire," which he read before the Wernerian Society of Edinburgh in May, 1830 .

Immediately after these beginnings were being made in opening out the rich storehouse of ancient fish-life contained in the Scottish Old Red Sandstone strata, the equally interesting trea sures of the Carboniferous rocks in the neighbourhood of Edinburgh had begun to attract notice. The greatest possible interest was excited among Edinburgh naturalists by Hibbert's discovery of the fossiliferous nature of the limestone of Burdiehouse, a member of the Lower Carboniferous series, and the Royal Society of Edinburgh co-operated energetically with that gentleman in securing a large collection of the animal remains which it contained. These comprised not only entire specimens of numerous small fishes, but also large detached spines and scales, and, above all, enormous conical teeth, some of which attained a length $o^{f}$ $3 \frac{3}{4}$ inches, and a width of $1 \frac{1}{2}$ inch at the base.

In the year 1833 the first livraison of Agassiz's "Recherches sur les Poissons fossiles" was given to the world. Already a goodly array of Continental writers had published accounts and figures of fossil fishes from various strata. Of these may be mentioned : Mylius, Knorr and Walchner, Wolfart, Scheuchzer, Volta, Bronn, Cuvier, and De Blainville; and a few also in England, such as Lhwyd, Mantell, and Sowerby had made observations upon similar fossils which had come under their notice. Large collections, both public and private, had also been formed. But as yet no satisfactory basis had been found for the comparison of fossil with living forms, and the vast treasures which were to be added to our knowledge of the succession of ichthyic life on the globe were, it may be said, as yet entirely unknown. It was reserved for Agassiz to lay the first secure foundations for this knowledge, and to become, as he is so often and so worthily styled, the father of fossil ichthyology.

Upon the studies to which he now directed his attention, and which were so largely to contribute to his world-wide reputation, Agassiz brought to bear the indispensable qualifications of an intimate acquaintance with recent ichthyology as well as with zoology and comparative anatomy in general. And in pursuing his investigations into the ichthyology of bygone ages, he soon became aware that no satisfactory place could be found in the Cuvierian system of classification for an extensive array of extinct fishes, which prevailed especially during the great palrozoic and secondary epochs. They bore affinity both to the sturgeon, classed by Cuvier among the Pisces cartilaginei, and to the American Lepidosteus and African Polypterus, whose place was then considered to be in the Malacopteryyian or soft-finned division of the Pisces ossei. The point in their configuration, by which Agassiz was more especially struck, was their possession of strong, bony, and usually glistening scales, the last-mentioned peculiarity suggesting the term "ganoid," as expressive of their distinctive aspect. The study of these ancient "enamelledscaled" fishes seems to have formed the spring to the conception of his new classification of fishes, according to their scales, into the four orders of Ganoidei, Placoidei, Ctenoidei, and Cycloidei. Working on the basis of this classification, he commenced the publication of his great work, and had alrèady, as he tells us, become acquainted with : ix hundred species of fossil fishes, when 
in 1834 he visited Great Britain for the first time, and his studies received a fresh impetus from the wealth of new forms which he found in Fnglish collections. In Scotland, too, collectors had been bestirring themselves, for besides what we have already noticed as having been done by Sedgwick, Murchison, Hibbert, and the Royal Society of Edinburgh, Traill had made a valuable collection from the Old Red Sandstone of Orkney; Knight of Aberdeen from the same formation at Gamrie; Lord Greenock had discovered the richness, in fish remains, of the Carboniferous shales at Wardie; and many Scottish specimens had also been collected by Jameson, Torrie, Buckland, and others.

The British Association met in 1834 at Edinburgh, and Agassiz was then introduced by Buckland to the Geological Section immediately after Hibbert had read a paper, in which he considered the gigantic teeth and bones found at Burdiehouse to "resemble those of Saurian reptiles." Their piscine nature was, however, at once detected by the accomplished Swiss naturalist, and the requisite material having been willingly handed over to him, he prepared and read, two days afterwards, a "Report on the Fossil Fishes of Scotland," in which several new genera are named. Mos! of the Scottish material obtained by Agassiz at this time was published in detail in the fasciculus of his great work, which appeared in 1835 , the Devonian forms including the genera Cephalaspis, Acanthodes, Cheiracanthus, Cheirolepis, Dipterus, and Osteolepis; while those from Carboniferous rocks were referred to Amblypterus, Palconiscus, Eurynotus, Pygopterus, Megalichthys, Gyracanthus, Tristuchius, Ctenopiychius, \&c.

Agassiz revisited Scotland in 1842 , and was present at the meeting of the British Association held that year at Glasgow. By this time the material for the further study and description of Scottish fossil fish remains had vastly increased. Large collections from the Old Red Sandstone beds of Cromarty and Moray. shire had been made by Hugh Miller, Dr. Malcolmson, Lady Gordon-Cumming, and Mr. Alexander Robertson. The collections of Lord Enniskillen and Sir Philip Egerton, which already, at the time of Agassiz's first visit to Great Britain, afforded a magnificent display of English and foreign species, now contained a choice selection also from Scotiand. Carboniferous forms had been assiduously collected by Dr. Rankin of Carluke and others. The large accession of material from the Old Red Sandstone enabled Agassiz in 1842 to lay before the British Association a "Report on the Fossil Fishes of the Devonian System," which finishes with a list of fifty-five species belonging to twenty genera.

His great work, the "Recherches sur les Poissons fossiles," was completed in 1843 , and in it was inserted a general list of all the fossil fishes which had till then come under his notice. Here we find ninety-nine species named from Scottish deposits, but, unfortunately, descriptions only of twenty-five were included in the text. The others he reserved for a projected series of supplementary monographs, of which only one ever appeared, namely, that on the fishes of the Old Red Sandstone, which was completed in 1846 . In this work sixty-seven Scottish species are figured and described, and some improvements in classification effected by the establishment of the new families of Cephalaspida, Acanthodide, and Saurodipterini, the two former being dismembered from the old heterogeneous Lepidoidei, and the latter partly from the Lepidoidei and partly from the so-called Sxuroidei.

In offering a few words of comment upon the labours of Agassiz in this department, the highest tribute of honour must be paid to him for the position to which he raised the science of fossil ichthyology, as well as for the enormous amount of work which he accomplished in so short a time. Eminent as well in other branches of zoology, his name will go down to posterity as that of one of the greatest naturalists of the present cenlury. To him we owe the establishment of the order of Ganoid fishes, the description of an enormous array of genera and species, and the first valuable generalisations as to the history and succession of ichthyic life on the globe. An opponent of the so-called vertebral theory of the skull, as held by Oken, and modified by Owen and others, as well as of the doctrine of descent, he nevertheless pointed out what, as Prof. Marsh says, "is now thought to be one of the strongest points in favour of evolution," namely, the correspondence between the heterocercal character of the tail in the embryos of modern osseous fishes, and the prevalence of that form among the adult fishes of the older formations, stating, in fact, that "les poissons fossiles du vieux grès rouge representent réellement l'âge embryonique du règne des poissons." But it is hardly possible for the zoologist of the present day to suppress some feeling of wonder that a man, so well versed in general zoology and anatomy as Agassiz, should have based his classification of fishes upon characters so trivial as the mere external aspect of their scales, or that he should have distinguished many of the families into which he divided the order of Ganoids by characters equally superficial. We may quote, for instance, his inclusion among the Ganoids of the Pipe-fishes, Siluroids, GlobeGshes, and Trunk-fishes, merely on account of their bony scutes ; the entirely artificial nature of the distinction which he drew between his Ganoid families of "Lepidoids" and "Sauroids," and the consequent utterly heterogeneous character of both ; the similarly unsatisfactory nature of his family of Calacanthi, into which he even introduced the recent Teleostean Arapaima;and so on. However, it is at the same time only natural that he should have been imperfectly acquainted with the anatomy of the ancient Ganoids, considering the as yet comparatively scanty material at his disposal, and it is also evident that, had he devoted more time to the elucidation of osteological detail, he could not possibly have gone over the same enormuls amount of ground within so limited a period.

Agassiz's classification of fishes was at first eagerly accepted by geologists and others, largely on account of its supposed convenience. It could not, however, stand the test of anatomical inquiry, and was soon superseded by the system proposed by Johannes Müller in 1844 , which, with various minor modifications, is the one still adhered to by most zoologists. Such, however, was the influence of Agassiz, and such the supposed "convenience" of his system, that we find it in use, especially amongst geologists and "palæontologists," years after Muiller's great paper "Ueber den Bau und die Grenzen der Ganoiden" was published.

The large fossil creature whose laniary teeth, sometimes four or five inches in length, suggested the idea of a "Saurian reptile" to Hibbert, and which was rightly placed among the fishes by Agassiz, received from him the not inappropriate name of Mesalichthys Hibberti. With its remains, however, those of a much smaller fish, with glossy angular scales, were at the time unfortunately confounded, but there can be no doubt that the name Megalichthys was suggested by the large teeth, and properly belonged to their possessor. Nevertheless, some time afterwards, on visiting Leeds, and finding in the Museum there the head of an example of the smaller fish, Agassiz described and frgured it in a subsequent number of the "Poissons fossiles" as Megalichthys Hibberti, while for the real and original Megit luchthys, aloug with some Old Red species he founded the genus Holoptychius. Prof. Owen, however, in his "Odontography" $(1840-45)$, elevated the Carboniferous "Holoptychius" Hibbcrti into the new genus Rhizvdus, giving also many important detail regarding the microscopic structure of the teeth. The claims of Rhizodus to generic distinction were stoutly disputed by Agassiz in his work on the fishes of the Old Red Sandstone. Subsequent investigation has, however, not only proved the validity of Rhizodus as a genus, but also that it cannot even be included in the same family with Holoptychius. In the same work Owen described the remarkable microscopic structure of the conical teeth from the Old Red Sandstone of Morayshire, to which he gave the name of Dendrodus.

The next writer on Scottish fossil fishes who claims attention is Hugh Miller, who devoted his chief attention to them, and whose collection of "Old Red" forms furnished many of the types described and figured by Agassiz in his "Monorraphie des Poissons fossiles du Vieux Grès Rouge," as well as many which were also figured by himself.

Among Miller's fascinating popular descriptions of scenery, geological strueture, and fossil fishes, we find some genuine touches of original palæontological observation, which quite sufficiently indicate what his powers in that direction might have been, bad they been properly developed. We find, for instance, that he was quite aware that Cheirolepis was not an Acanthodian, though it was classed by Agassiz in that family. We find a very creditable restoration of Osteolepis, infinitely superior to that given by Agassiz some years afterwards, and hardly inferior to that given by the accomplished Pander; and we find him correctly interpreting as the ventral surface of Pterichthys that aspect of the creature erroneously represented by Agassiz as the dorsal. He also showed that Agassiz's Polyphractus, supposed by him to be a genus allied to Plerichthys, was nothing more than the cranial shield of a Dipterus. He likewise discovered the dentition of Dipterus, which, with the structure of the palatal 
aspect of the skull, afterwards proved of such importance in determining the affinity of that genus to the recent Dipnoi. Many important original observations and figures were given by him regarding the cranial osteology of Osteolepis and Diplopterus, as well as of the gigantic Asterolepis.

$\mathrm{M}^{\prime} \mathrm{Coy}$, while engaged in naming and describing the palæozoic fossils of the Woodwardian Museum at Cambridge, among which were a considerable number of Scottish fossil fish remains, principally from the Old Red Flags of Orkney, published in 1848 some account of his work in naming and describing genera and species. It is greatly to be feared that the enormous field over which his other palæontological researches extended had not afforded him the time and opportunity to acquire the necessary experience in deciphering fish remains, without which the liability to error is not only natural but imminent.

To M'Coy we owe the separation of the true Cephalaspide from the other fishes, Pterichthys and Coccosteus, with which Agassiz bad associated them, and the establishment of the latter as a group by themselves under the name of Placodermata; also the term "diphycercal," applied to that form of fish-tail in which the vertebral axis is, as in the heterocercal form, gradually attenuated, but runs straight backwards instead of turning up, and the fin-rays being developed equally, or nearly so, above and below, a more or less rhombic and symmetrical form of caudal fin is produced.

The diphycercal tail is a more primitive or embryonic form than the heterocercal, of which the modern humocercal tail is again a further specialisation. That this is the case is evident to any one who will carefully compare a proper series of tails of recent and fossil fishes. Prof. Alexander Agassiz has recently put the matter in a perfectly clear and unmistakable light by showing that the tail in embryo Pleuronectide is first diphycercal (leptocardial), then heterocercal, and finally assumes the homocercal form of the adult in which the heterocercy becomes to external appearance completely obliterated.

Sir Philip Grey-Egerton, whom we are glad to refer to as a veteran naturalist, still living amongst us, and continuing to take the warmest interest in the progress of the science to which he has himself contributed so much, has not in his writings sought to alter the classification of Agassiz save in one or two points of secondary importance. He has busied himself with the description of new genera and species, so largely supplied by his own magnificent collection as well as by that of his close personal friend, the Earl of Enniskillen, to whom also the friends of fossil ichthyology owe a lasting debt of gratitude. Although Sir Philip's descriptions mainly relate to fishes from the newer formations in England, he has also made some important contributions to our knowledge of Scottish forms. In his paper on Pterichthys (1848), written in conjunction with Hugh Miller, he corrected some of the mistakes into which Agassiz had fallen with regard to the arrangement of the plates in that genus. In another communication, "On the Nomenclature of the Devonian Fishes," he offered some able criticisms on Prof. M'Coy's work in that department, and added as a supplement a series of interesting extracts from letters by Hugh Miller on the structure of Coccosteus. The tenth decade of the Geological Survey, published in I86I, contains also from Sir Philip's pen a description of Tiistichopterus alatus, one of Mr. Peach's most interesting discoveries in the Old Red Sanditone of John o' Groats, as well as of several beautiful little Acanthodian fishes, two from Caithness, also discovered by $\mathrm{Mr}$. Peach, and others from the grey beds of Forfarshire, brought to light by several industrious Forfarshire collectors, among whom were the Rev. Hugh Mitchell, the Rev. Henry Brewster, Mr. Walter M'Nicol, and Mr. Powrie of Reswallie. To Scottish carboniferous ichthyology Sir Philip Grey-Egerton also contributed descriptions of two new selachian species, Ctenacanthus hybodoides and C. nodosus ; and his paper on the probable identity of Agassiz's genera, Pleuracanthus and Diplodus, is also of equal importance to the investigator of the fossil contents of the Scottish as of the English coal measures.

A third great era in the history of palaeozoic ichthyology may be said to have commenced with the publication of the researches of the distinguished Russian naturalist, Dr. Christian Heinrich Pander. With his first great work, the "Monographie der fossilen Fische des silurischen Systems des russisch-baltischen Gouvernements," published in $185^{6}$, we have here nothing to do, save to remark that if the singular little tooth-like bodies, known as "conodonts," be in reality what many at the present day suppose them to be, namely, the teeth of Myxinoid fishes, then we shall have abundant evidence of the prevalence of theselowly organised fishes far back in Lower Silurian times. It is his thre subsequent publications, on the "Placodermi," on the "Cteno. dipterini," and on the "Saurodipterini, \&c.," appearing respec tively in $1857,185^{8}$, and 1860 , which attract our attention, dealing as they do with the fishes of the Old Red Sandstone, and very largely with Scottish specimens. Fish remains are of frequent occurrence in the Old Red Sandstone of Russia; many had been previously described by Eichwald as far back as 1839, as well as by Agassiz in his monograph of the fishes of the Old Red Sandstone. These remains are, however, mostly very fragmentary; to read them aright, comparison with more entire fishes was necessary, and this want was supplied by the liberality and enthusiasm of a member of the Russian Academ;, Herr von Hamel, who undertook a journey to Scotland, and, having collected a large number of specimens both in Caithness and in Orkney, packed them in barrels, and shipped them off bodily to St. Petersburg. There they were placed at Pander's disposal for description, and the results are embodied in the three works last quoted. The main feature in Pander's work was his elucidation of structure, and his clear insight into the fact that only by careful and laborious investigation into the structural features of the skeleton, external and internal, can we hope to determine the natural affinities of fossil fishes. Here his achievements surpassed all that had been previously done in palæozoic ichthyology. The structure of the Placodermata (Pterichthys, Coccosteus, Asterolepis, Heterosteus) is minutely described and illustrated, as also of the Saurodipterini (Osteolepis, Diplopicrus). A like treatment is accorded to Dipterus, for which he institutes the family Ctenodipterini, in which he also provisionally includes Ceratodus, then only known as a mesozoic fossil, and to Cheirolepis, which he also erects into a distinct family, fully corroborating the views of Hugh Miller and of Giebel as to its place not being among the Acanthodei, as Agassiz had imagined, as well as indicating that he was not unaware of its resemblance to Palconiscus. The singularly beautiful and complicated microscopic structure of the Old Red Sandstone teeth, so well known as Dendrodus, Lamnodus, \&c., is minutely described and magnificently delineated.

From his elaborate and truly scientific researches, Pander derived one interesting generalisation, which presently rose to extreme importance. Johannes Müller had long before shown that the recent Lepiclosteus and Polypterus, classed together by Agassiz in one family, that of the sc-called Sauroidei, were representatives of totally distinct groups of Ganoids; but among all the fossil fisbes of the order, he could for Polypterus find no ally. Pander, however, pointed out that, far from Polypterus having no ally in past ages, it is to it rather than to Lepidosteus that the affinities of many of the Old Red Sandstone Ganoids point, and more especially those of the group lnown as Saurodipterini.

In 1858 Huxley published observations on the genera Cephalaspis and Pteraspir, having in the previous year described the new genera Glyptolcemus and Phaneropleuron, with observations on the genus Holoptychius. In 1861 his "Essay on the Systematic Arrangement of the Fishes of the Devonian Epoch" appeared, in which the whole subject of the classification of the Ganoids, and especially of those of the Old Red Sandstone was discussed.

Pander noticed the fact that many of the Old Red Sandstone Ganoids were more allied to Polypterus than to Lepidosteus. Huxley, proceeding farther in the same direction, instituted the sub-order Crossofterygida, of which Polypterus and Calamoichthys are the sole living representatives, but which in palæozoic times included an extensive assemblage of forms, collectively equivalent to Agassiz's Colacanthi and Saurodipterini. The heterogeneous nature of Agassiz's " Colacanthi" was pointed out, and the term very properly limited to the peculiar genera Colacanthus, Undina, Holophagus, and Macropoma, none of which are, however, found in the Old Red Sandstone. The remaining Agassizian Coelacanths (Holoptychius, Glyptolepis, \&c.), were placed in a new family, that of the Glyplodipterini, and here are also included forms both with rounded and rhombic scales. Pander's family of "Dendrodonts" was considered to be probably based on teeth of fishes belonging to the Glyptodipterini. But the Russian author's family of Ctenodipterini and Agassiz's Sutroditterini are retained and likewise placed in the Crossopterygian sub-order, which lastly includes also the Fhaneropleurmi, constituted by the singular genus Phanerpp'euron.

The next important point in Prof. Huxley's "Essay" is the attention which he drew to the singular ties which connect the recent genus Lepidosiren (the Australian Ceratodus being at that 
time still undiscovered) with the cycloidal-scaled members of the Crossopterygide. And although he was not fully aware of the extreme closeness of the relationship between the recent Sirenoids and one of his Crossopterygian families, the Clenodiplerini, he, nevertheless, touched the spring which subsequently disclosed to us the true position of that family, when he compared the teeth of Lepidosiren with those of Dipterus.

On the other hand the American bony pike or Lepidosteus, is made the living type of another great assemblage, of which the Old Red Sandstone genus Cheirolepis "ought perhaps to be regarded as the earliest known form." To this sub-order of Lepidosteida merely a passing and imperfect notice is accorded, but it is nevertheless clear that the author means it to embrace both the heterocercal Palconiscide of the upper palæozoic rocks, and that great array of semi-heterocercal rhombic-scaled forms (Lepidotus, Dapedius, Pholidophorus, \&c.), which in mesozoic times constituted the great bulk of the Ganoid order.

The se two great sub-orders of Crossopteryoida and Lepidosteida, with the addition of the recent Amiadce, are equivalent to Müller's Ganoidei Holostei. The other sub-order of the Berlin anatomist, that of the Chondrostei or sturgeons was accepted, and to it the remarkable Old Red family of Cephalaspida, referred, provisionally at least, while into a fifth sub-order was erected the problematic group of Acanthodida, which, in their organisation, seem to combine so many of the characters both of ganoids and of sharks.

Undoubtedly, the weakest point in Prof. Huxley's "essay" is the attempt which he made to show, by comparison of the exoskeletal plates of Coccosteus with the bones visible on the exterior of the skeleton of many recent siluroids, that there was a possibility at least of the enigmatical group of Placodermata turning out to belong to the great order of Teleostei, or ordinary bony fishes, "hitherto supposed to be entirely absent from formations of palrozuic age." Recent discoveries in the palæozoic rocks of America point, as we shall presently see, to another, and perhaps more probable, solution of the question.

Mr. Powrie, of Reswallie, has contributed several papers on the fishes of the Old Red Sandstone of Forfarshire, and to him we owe the definition of the genus Euacanthus, comprising four species, and also of a new species of Purexus. The remarkable group of Cephalaspida has been monographed by Prof. E. Ray Lankester in the volumes of the Palæontographical Society for 1868 and 1870 .

The true affinities of the Old Red Sandstone genus Dipterus, and the carboniferous Ctenodus, foreshadowed by Mr. Huxley in $\mathbf{1 8 6 1}$, were thoroughly cleared up by the discovery of the living Ceratodus Forsteri in the rivers of Queensland. The Ctenoiodipterini were definitely placed among the Dipnoi by Dr. Günther in his account of the structure of Ceratodus (Phil. Trans., 1871), and subsequent observation has amply confirmed the correctness of his views on this point.

The discovery in the Devonian rocks of North America of the gigantic Placoderm, named by Prof. Newberry Dinichthys, seems at last to throw some light on the position of that remarkable group of extinct fishes. In Dinichthys we have a form, apparently closely allied to Coccosteus, but also possessed of a dentition in many respects resembling that of the recent Lepidosiren. It seems, therefore, not unlikely that the Placodermata will eventually turn out to have been an aberrant group of loricated Dipnoi.

Recent progress with regard to the structure and affinities of Scottish Carboniferous fishes is so inseparably connected with the study of the fishes of the same great period in England, that kere the sister kingdoms cannot easily be treated separately, except as regards local and stratigraphical lists of genera and species. Descriptive papers dealing with English specimens are of equal importance to the student resident in Scotland. Scottish fossil ichthyology is therefore equally indebted to Prof. Youn $y$ for his descriptions (published in 1866) of the remarkable Platysomid genera Amphicentrum (= Cheirodus, $\mathrm{M}^{\prime} \mathrm{Coy}$ ) and Mesolepis, as well as of the little Platysomus parvulus, a species named but not described by Agassiz, as all of them occur in the Scottish coal-measures, although Prof. Young's descriptions were taken from the more perfect examples furnished by the North Staffordshire district. Prof. Young, in the same paper, also correctly pointed out the affinity to Mesolepis, and consequently also to Platysomus, of our well-known Scottish Lower Carboniferous genus Eurynotus, but I fear we cannot accept his sub-order Lepidop'euride, in which he sought to include both the Platysomid and Pycnodont fishes. His paper on "Carboni- ferous Glyptodipterines" (Rhizodopsis, Rhizodus, \&c.), also published in 1866 , deals largely with Scottish specimens, and with forms which constantly come under the notice of the Scottish collector. Prof. Young has given, besides, several other notices of fish remains from the Carboniferous rocks of the West of Scotland, as has also Mr. James Thomson, of Glasgow, among whose contributions may be specially mentioned his description and figure of an enormous Acanthodes from the Palace Craig Ironstone of Lanarkshire. Of purely local work, a very creditable example, though requiring some revision, is the list of carboniferous fishes in the "Catalogue of the Western Scottish Fossils," compiled by Messrs. Young and Armstrong, published first in the Transactions of the Geological Society of Glasgow, and afterwards issued as one of the "British Association Guide Books" on the occasion of the meeting of that body at Glasgow in 1876 .

Here we must for the present take leave of our subject. Much remains still to be done both as regards general research into the structure and classification of palæozoic fishes, and as regards the rectification of species, and the compiling of reliable catalogues of those which occur as well in Scotland as in other divisions of our common country of Great Britain. The work must, however, necessarily be slow, as nothing is more injurious to the cause of palæontology than undue haste, whether in descriptive work or in attempted generalisation.

\section{THE STRUCTURE AND ORIGIN OF STRATIFIED ROCKS ${ }^{\mathrm{x}}$}

I $N$ his address last year the author treated exclusively of the structure and origin of limestones, and now confined his remarks to the structure and origin of all other stratified rocks. In the first place he considered the question of the origin in crystalline rocks of the material, and described those peculiarities in external form and internal structure, which would enable us to determine the true nature and origin of the grains of sand and other materials met with in stratified rocks. He next considered the formation of the very fine-grained particles met with in clays and mud, as derived from the mechanical wearing down of minerals like quartz, which cannot be decomposed, or from the chemical decomposition of others like felspar and hornblende. The materials thus formed mechanically and chemically by the complete weathering of crystalline rocks are to a great extent in a state of equilibrium, and not prone to undergo further change, whereas the minerals in volcanic ash are to a considerable extent in a state of such unstable equilibrium that they soon undergo further important changes. A deposit of this nature might thus soon be more altered than one of the other type in vast geological periods. Amongst other facts of the like kind it may be named that the large amount of very fine-grained micaceous mud deposits found in some of our earlier strata was shown to be in all probability derived from certain quartz felsites, in which the base is to a large extent composed of very minute crystals of mica.

Havi $\mathrm{g}$ thus traced the origin of the material, the method of observing loose unconsolidated deposits was described, and afterwards the general conclusions so far arrived at. In the case of quartz sands it was shown that, though they might appear almost identical to the naked eye, they may be divided into five wellmarked varieties, which however pass gradually one into the other. These five types are as follows :-

I. Normal, angular, fresh-formed sand, as derived almost directly from granitic or schistose rocks.

2. Well-worn sand, in rounded grains, the original angles being completely lost, and the surface looking like ground glass. 3. Sand mechanically broken into sharp, angular chips, showing a glassy fracture.

4. Sand having the grains chemically corroded, so as to produce a peculiar texture of the surface, differing from that of either worn grains or crystals.

5. Sand in which the grains have a perfect crystalline outline, in some cases undoubtedly due to the deposition of quartz over rounded or angular nuclei of ordinary non-crystalline sand.

On the whole, then, we may say that these different types are due to different kinds of mechanical or chemical changes, affecting grains originally derived from crystalline rocks.

In further considering sands more or less worn mechanically,

I Abstract by the Author of the President's Address at the anniversary meeting of the Geslogical Society, February 20 , by $\mathbf{H}$ C. S srby, LL.D., F.R.S. 